\title{
Bone Marrow Cells Lymphocyte Activity of Pregnant Mice with Therapy of E. scaber and S. androgynus Post Infection Salmonella typhimurium
}

\author{
Muhammad Basyaruddin ${ }^{1,2^{*}}$, Moh. Sasmito Djati ${ }^{2^{*}}$, Sri Rahayu ${ }^{2}$ \\ ${ }^{1}$ Master Program of Biology, Faculty of Mathematics and Natural Sciences, University of Brawijaya, Malang, Indonesia \\ ${ }^{2}$ Laboratory of Animal Physiology, Department of Biology, Faculty of Mathematics and Natural Sciences, University of \\ Brawijaya, Malang, Indonesia
}

\begin{abstract}
Pregnancy can cause immune system changes. It is characterized by a decrease in the activity of immunocompetent cells. The use of antibiotics was intended to combat pathogenic microorganisms, but antibiotics have negative effects on pregnant women. The use of antibiotics can be replaced with extracts of Elephantopus scaber and Sauropus androgynus because both plants have chemical compounds that act as immunomodulators. This study was aimed to determine the activity of lymphocytes $\mathrm{B}_{2} 2 \mathrm{O}^{+}, \mathrm{TER} 119^{+}$, and $\mathrm{GR}-\mathrm{1}^{+}$on bone marrow pregnant mice given the combination of extracts of Elephantopus scaber and Sauropus androgynus after infected with Salmonella typhimurium. This research uses seven treatment groups name: (K-) $0.05 \% \mathrm{NaCMC}$ without bacterial infection; (K+) $0.05 \% \mathrm{NaCMC}$ infected by bacteria; (P1) E. scaber $200 \mathrm{mg} . \mathrm{kg}^{-1} \mathrm{BW}$ infected by bacteria; (P2) E. scaber $150 \mathrm{mg} . \mathrm{kg}^{-1} \mathrm{BW}$ and S. androgynus $37.5 \mathrm{mg} \cdot \mathrm{kg}^{-1} \mathrm{BW}$ infected by bacteria; (P3) E. scaber $100 \mathrm{mg} \cdot \mathrm{kg}^{-1} \mathrm{BW}$ and S. androgynus $75 \mathrm{mg} \cdot \mathrm{kg}^{-1} \mathrm{BW}$ infected by bacteria; (P4) E. scaber $50 \mathrm{mg} . \mathrm{kg}^{-1} \mathrm{BW}$ and S. androgynus $112.5 \mathrm{mg} \cdot \mathrm{kg}^{-1} \mathrm{BW}$ infected by bacteria; and (P5) S. androgynus $150 \mathrm{mg} . \mathrm{kg}^{-1} \mathrm{BW}$ infected bacteria. The initial dose of E. scaber and S. androgynus was $50 \mathrm{mg} \cdot \mathrm{kg}^{-1}$. Each treatment has three repetitions, surgery performed on day $12^{\text {th }}$ and $18^{\text {th }}$. Lymphocyte cells isolated from bone marrow, the obtained results were analyzed by flowcytometry and statistical analysis using SPSS 16.0 one-way ANOVA, Tukey test and path. Based on the results from ANOVA tables, the formulations on mice that can restore their normal conditions with $\mathrm{B} 22 \mathrm{O}^{+}$ cells is E. scaber $150 \mathrm{mg} \cdot \mathrm{kg}^{-1} \mathrm{BW}$ and S. androgynus $37.5 \mathrm{mg} \cdot \mathrm{kg}^{-1} \mathrm{BW}, \mathrm{TER} 119^{+}$cells is $S$. androgynus $150 \mathrm{mg} \cdot \mathrm{kg}^{-1} \mathrm{BW}$, while the GR-1 ${ }^{+}$cells affected by the surgery. Those three dose formulations can be used to obtain the optimum value which can increase the number of lymphocytes and not harmful to the developing fetus.
\end{abstract}

Keywords: Bone marrow, Elephantopus scaber, Lymphocyte, Pregnant mice, Sauropus androgynus

\section{INTRODUCTION}

Pregnancy in women will affect the physiological condition of the body. In the state, pregnant women will experience changes in their immune system, which is intended to facilitate embryo implantation, placental development, fetal tolerance initiated, as well as the defense of the maternal immune system [1]. Changes in the pregnant woman's immune system will lower the immune system [2], thus with such a situation pregnant women susceptible to disease [3].

One change that affects the immune system of pregnant women is Salmonella [4]. Previous study analyzed 200 blood samples and found that 129 women have positive samples of typhoid fever [5]. The ability of the bacteria causing typhoid fever because it has a Vi antigen capable of reducing the expenditure of $\mathrm{IL}-8$, which has the role of neutrophils inducers [6].

\footnotetext{
* Correspondence author:

Muhammad Basyaruddin

Email : elbasyary@gmail.com

Address : Laboratory of Animal Physiology, Department of Biology, University of Brawijaya, Jl. Veteran Malang, 65145
}

Intracelular facultative bacteria live and reproduce in varies of cell types, including macrophage which leads prominent in immunity. Celullar immunity mechanism is the most appropriate mechanism to do elimination, where antibody in blood circulation unable to reach progress antigens in cells [7]. Infection in pregnant women will affect the activity of immunocompetent cells that play a role in controlling the entry of viruses, bacteria and other pathogens. Influence exerted by pathogenic microorganisms will lead to symptoms of toxicity. Delays in handling would result in perforation, periontitis, loss of consciousness and death [2]. The infection will also cause damage to erythrocytes and through lysis [8]. Infection will result in inflammatory cells and affect the polymerase and differentiation of $B$ cells thus activity of erythrocyte disturbed [9].

The synthetic compounds administered to pregnant women to prevent immune deficiencies. However, this compound causes destructive ends effects that harm the mother and the fetus [2]. Therefore the need to look for 
alternatives with systemic effects found herbal medicine [10].

E. scaber and S. androgynus has been widely studied as a natural immunomodulator [11,12], but it is not known how the effect when both plants use together. Therefore, this study was aimed to determine the influence of $E$. scaber and $S$. androgynus on the activities of $\mathrm{B}_{2} 2 \mathrm{O}^{+}$cells, TER $119^{+}$, and $\mathrm{GR} 1^{+}$on pregnant mice infected by S. typhimurium.

\section{MATERIALS AND METHODS Design of Experiments}

This experimental research was conducted by using seven experimental groups, i.e. two control groups and five treatment groups. Surgery performed on the $12^{\text {th }}$ and $18^{\text {th }}$ after the animal was assumed to be pregnant by comparing the results of observation on treatment and control, as well as between the treatment groups.

Total of 42 Balb/C mice were divided into seven treatment groups, each group consisted of three replications. Mice got the same standard treatment of eat and drink ad libitum. An object of experimentation is pregnant female mice strains balb/c obtained from PT. Galaxy science Jember. Bacteria S. typhimurium was injected intraperitoneal. We used strains 444-D from the collection of the Laboratory of Microbiology, Faculty of Medicine, University of Brawijaya.

\section{Extract Preparation}

Simplicia obtained from medika materia, Batu. The extract was made by maceration in $70 \%$ ethanol solution of $1: 3$ for $1 \times 24$ hours with occasional stirring. After 24 hours, the results were filtered using a Buchner funnel to get the plsntd extract, then evaporated at evaporator tube rotating speed of 200rpm at a temperature of $40^{\circ} \mathrm{C}$ waterbath. The condensed filtrate was weighed and prepared by dissolving treatment with $0.05 \% \mathrm{NaCMC}$ and administered orally to the mice.

\section{Treatment}

Pregnant mice were given the extract of $E$. scaber and $S$. androgynus referred to the design (Table 1). The initial dose of $E$. scaber and $S$. androgynus was $50 \mathrm{mg} . \mathrm{kg}^{-1} \mathrm{BW}$. Each treatment contained three repetitions.

Later on $5^{\text {th }}$ day after administration of the extract, the mice infected with the bacterium $S$. typhimurium concentration of $10^{7}$ cfu. $\mathrm{mL}^{-1}$. Administration of extracts combination was continued until surgery on the $12^{\text {th }}$ and $18^{\text {th }}$ day. Extracts were given by sonde daily before meal.

Table 1. Experiment design of mice groups

\begin{tabular}{cccc}
\hline Mice & Bacterial & \multicolumn{2}{c}{ Therapy $\left(\mathbf{m g}^{\left.-\mathbf{k g}^{-1} \mathbf{B W}\right)}\right.$} \\
\cline { 3 - 4 } Groups & Infection & E. scaber & S. androgynus \\
\hline $\mathrm{K}-$ & - & - & - \\
$\mathrm{K}+$ & infected & - & - \\
P1 & infected & 200 & - \\
P2 & infected & 150 & 37.5 \\
P3 & infected & 100 & 75 \\
P4 & infected & 50 & 112.5 \\
P5 & infected & - & 150 \\
\hline
\end{tabular}

Note: Control (K) were given $0.05 \% \mathrm{NaCMC}$

\section{Isolation of Lymphocytes}

Isolated bone marrow flushed with PBS using a syringe and placed in polypropylene tubes, whereas the isolation of peripheral blood samples were taken from the heart inserted into propylene and added PBS and centrifuged 2500 rpm for $5 \mathrm{~min}$ at $4^{\circ} \mathrm{C}$. Pellet resuspended in $1 \mathrm{~mL}$ of PBS to be taken $30 \mu \mathrm{L}$ then put in a microtube containing $1 \mathrm{~mL}$ of PBS for re centrifuged at 1500 rpm temperature of $10^{\circ} \mathrm{C}$ for $5 \mathrm{~min}$. Pellets then added PBS containing FITC monoclonal antibody anti-B220, anti-TER-PE 119 and PE-anti GR-1 for $50 \mu \mathrm{L}$ and incubated for 20-30 min prior to analysis using flowcytometry.

\section{Analysis of flowcytometry}

The cell suspension was transferred into a cuvet flowcytometer, added $500 \mathrm{~mL}$ of PBS and homogenized. The setting of flowcytometer has been on acquired by the computer. After all the instruments were ready, cuvet mounted on the nozzle BD FACS Calibur TM Bioscience flowcytometry. Data from flowcytometer was subsequently processed with software of BD CellQuest $\mathrm{PRO}^{\mathrm{TM}}$ and displayed as a histogram.

\section{Data Analysis}

The results of the relative number of $\mathrm{B}^{2} 2 \mathrm{O}^{+}$ cells, TER119 ${ }^{+}$and $\mathrm{GR}-1^{+}$were tested its normality with SPSS 16.0. Furthermore, the data were tested by ANOVA, and if there is significance then proceed to the Tukey test.

\section{RESULT AND DISCUSSION $\mathrm{B220}^{+}$Cells}

Flowcytometry analysis of bone marrow showed the average relative number of $\mathrm{B} 220^{+}$ cells which was significantly different $(P<0.05)$ to the $\mathrm{B}_{2} 2 \mathrm{O}^{+}$cell activation. The results ANOVA showed that the administration of $70 \%$ ethanol extract of the leaves of $E$. scaber and leaves of $S$. 
androgynus were potential to increase the relative amount of $\mathrm{B}^{2} 20^{+}$cells. Figure 1 is the expression generated from flowcytometry. It described the increase in the relative number of $\mathrm{B} 220^{+}$cells. The real difference indicated that $\mathrm{P} 2$ treatment (ES $150 \mathrm{mg} . \mathrm{kg}^{-1}$ : SA $37.5 \mathrm{mg} \cdot \mathrm{kg}^{-1}$ ) with significance value of $p<0.05$.

The existence of foreign objects that enter the body will be received by surface receptors $[13,14]$. Incoming antigens will trigger nonspecific immune system by forming imunocomplex through the production of antibodies and some cytokines [15]. Other research found that flavonoid compound and the injection of $S$. typhimurium increased the proliferation of lymphocytes [9]. Thus its existence has immunostimulatory effects to stimulate the production of IL-2 [16].

Increased $\mathrm{B}^{2} 2 \mathrm{O}^{+}$cells showed an increase in plasma cell populations. It because the $B 220^{+}$ cells are a subset of CD45R isoform predominantly expressed on all B-lymphocytes and plasma cells regulate the development. Increased plasma cells showed that the $70 \%$ ethanol extract of E. scaber and S. androgynus have immunostimulatory effects. Middleton [16] revealed the presence of flavonoids can inhibit the activity of MAPK (mitogen-Activated Protein Kinase) that causes posporilasi various transcription factor protein needed for protein synthesis. The induction of MAPK protein would activate the

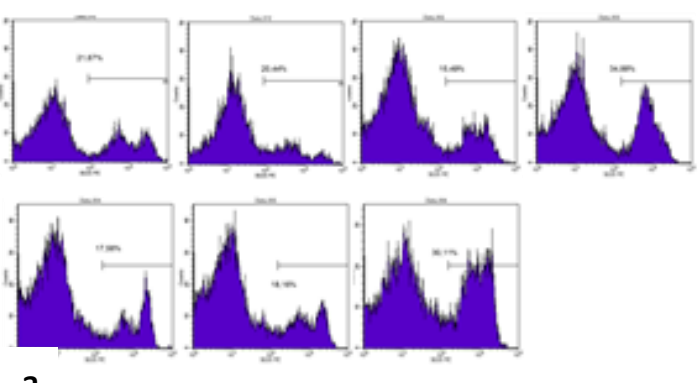

transcription factor NF-kB is a transcription factor in the proliferation and differentiation of $\mathrm{B} 22 \mathrm{O}^{+}$ cells through regulation of cytokines [17].

\section{TER119 $^{+}$cells}

The mean relative number of TER- $119^{+}$cells was analyzed by flowcytometry (Fig. 2.) There is a decrease compared to the control. SPSS analysis showed that the relative number of TER $119^{+}$cells is significantly different for the P5 treatment (SA 150mg. kg $\left.{ }^{-1} \mathrm{BW}\right)$.

TER- $119^{+}$cells are antigen expressed on erythrocytes. Viability of erythrocytes in normal mice is 42-56 days. Otherwise, 3-4 days for erythropoiesis, anemia, hypoxia and inflammation will lead to faster and release eritropoesis erythrocytes in peripheral area [18]. Decreased expression of TER-119 ${ }^{+}$cells caused by an infection of S. typhimurium. Sudoyo [8] described the Salmonella bacteria have the ability to live well in the gastrointestinal tract and other organs, thus causing an inflammatory reaction. Inflammatory process will affect the activity of erythrocyte during oxidation will cause damage to hemoglobin. Erythrocytes will be separated from the cytoplasm, whereas macrophage cells will phagocytose abnormal erythrocyte [19]. The effect of extract gives a stable condition or equal to normal treatment. It is because pregnant mice require adequate nutrition, thus proliferation and differentiation does not work faster.

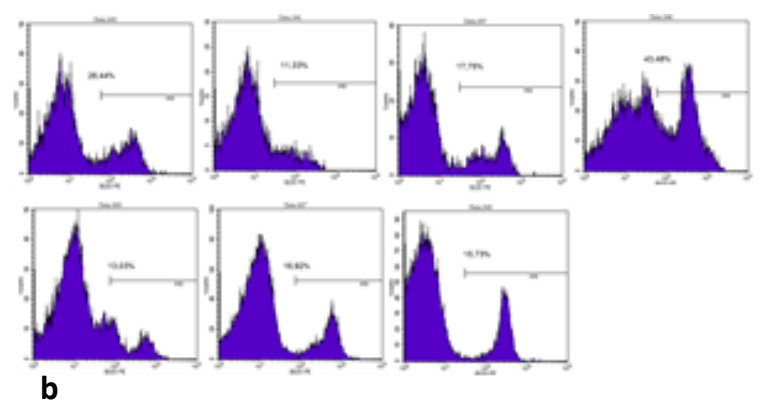

B220+

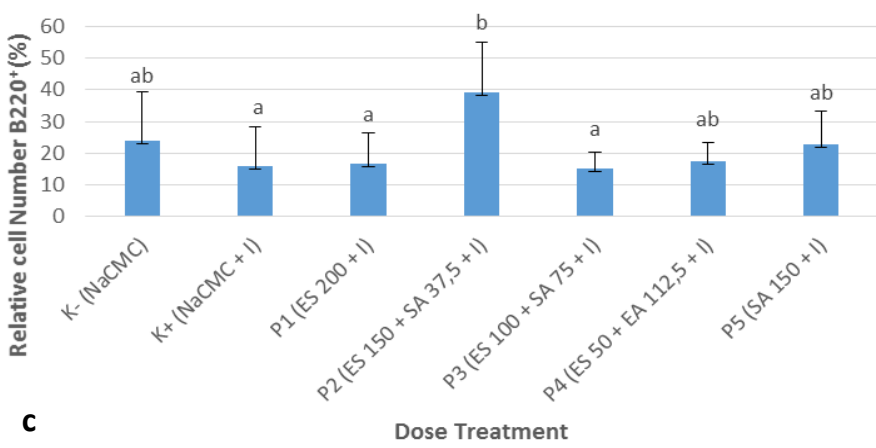

Figure 1. Expression of $\mathrm{B} 220^{+}$cells

Description: $\mathrm{ES}=$ Elephantopus scaber, $\mathrm{SA}=$ Sauropus androgynus, $\mathrm{I}=$ infected by Salmonella typhimurium a. day surgery to $12^{\text {th }} ;$ b. day surgery to $18^{\text {th }} ;$ c. mean relative number of $\mathrm{B}_{22} \mathrm{O}^{+}$cells (\%) 

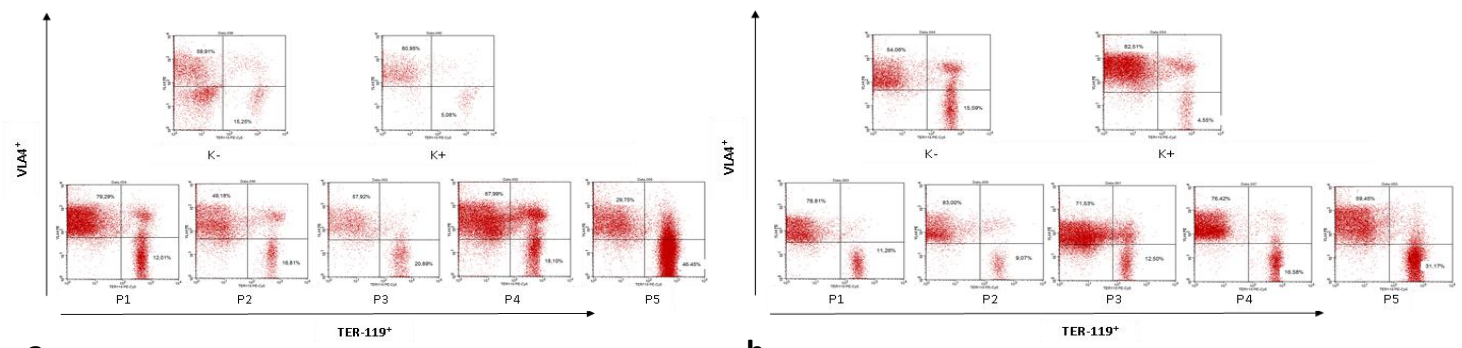

b

TER-119+

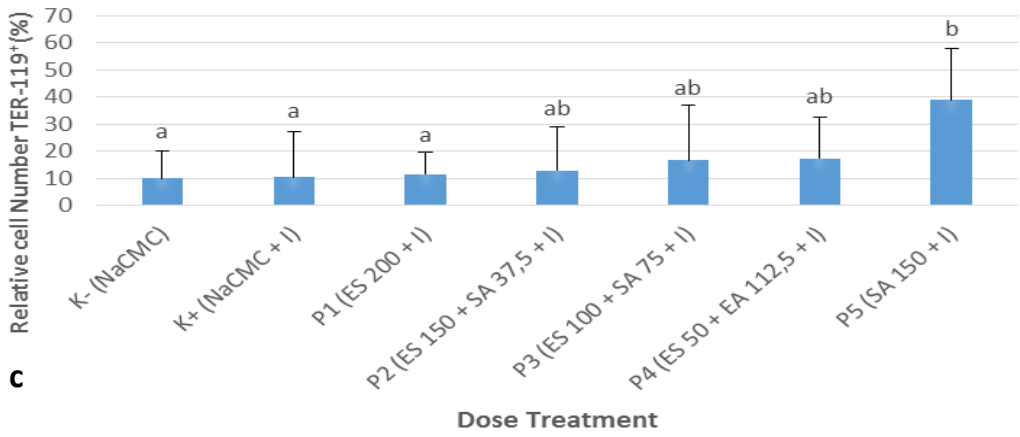

Figure 2. Expression of TER119 ${ }^{+}$cells

Description: ES=Elephantopus scaber, $\mathrm{SA}=$ Sauropus androgynus, $\mathrm{l}=$ infected by Salmonella typhimurium a. day surgery to $12^{\text {th }} ;$ b. day surgery to $18^{\text {th }} ;$ c. mean relative number of TER $119^{+}$cells (\%)

\section{$\mathrm{GR}^{+}$cells}

Expression of GR-1 $1^{+}$cell proliferation showed in Figure 3. Infection of $S$. thypimurium triggered cell deficiency $\mathrm{GR}-1^{+}$to phagocytose cells that have been damaged or abnormal. ANOVA results showed that the $70 \%$ ethanol extract of the leaves of $E$. scaber and $S$. androgynus can increase the $\mathrm{GR}-1^{+}$molecule but not significant ( $p>0.05$ ). Calculation continued to post hoc analysis with Tukey test. It showed that the treatment group had a significant difference to the control. Negative control group had an average increased compared to the positive control group. According to previous research, the increase in the number of neutrophils and IFN $\gamma$ cells in animals affected by an infection with Salmonella bacteria than uninfected animals [20]. Other study stated that in Balb/C mice were given Salmonella infection increased the number of leukocytes including neutrophils and IFNy significantly compared with the group treated with the standard feed [21].

Microorganisms will spur the immune system of the body's defense nonspecific starts with the way the body's defenses destroy bacteria and more complex through antibody production or manufacture of various cytokines [15]. Neutrophils $\left(\mathrm{GR}-1^{+}\right)$work on non-specific immune response pathway. The cytokine IFN $\gamma$ will act as immunomodulator through the regulation of gene expression to signal transduction. Neutrophil cells will express the receptor molecule with 1000 fast and stable molecule binds IFNץ [22]. After binding, there will be internalization, thus decreasing surface receptors. IFN $\gamma$ regulates expression on number of genes including complement receptor regulator, B lymphocyte stimulator, dendrites chemotactic factor, chemokine receptors, neutrophil chemotactic factors and proinflammatory cytokines.

\section{Path Analysis}

Path diagram was made based on the results on statistical analysis of the correlation (Fig. 4). Proliferation and differentiation of B lymphocyte cells are affected by the $S$. typhimurium infection and extract combinations. The antigen will be responded by expressing cell surface receptors, i.e. $B 220^{+}$, TER $119^{+}$and $\mathrm{Gr}-\mathrm{1}^{+}$. Day surgery affects the relative amount of macrophage cells as much as $13.03 \%$ and the relative number of cells suppresses TER $119^{+}$to $18.19 \%$.

Infection of $S$. thypimurium will increase the number of cells of neutrophils and cytokines IFN [20]. Infection also affects the activity of B cells. The cells that are not growing will be phagocytosed by macrophages thus the number will be reduced. The existence of the extract will maintain the number of B lymphocyte cells in proliferation and differentiation [19]. 

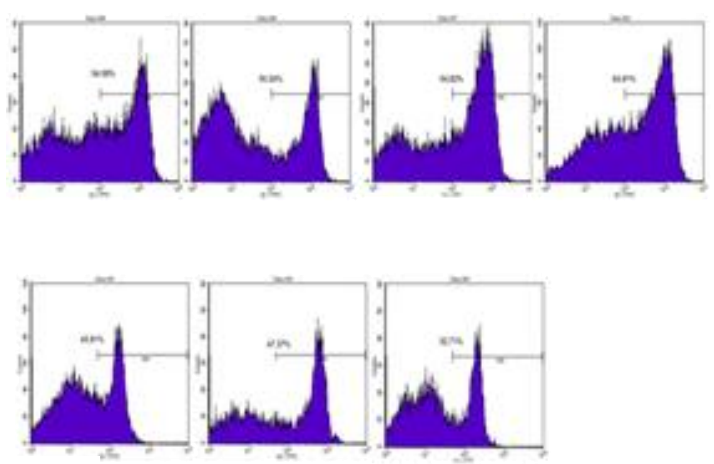

a
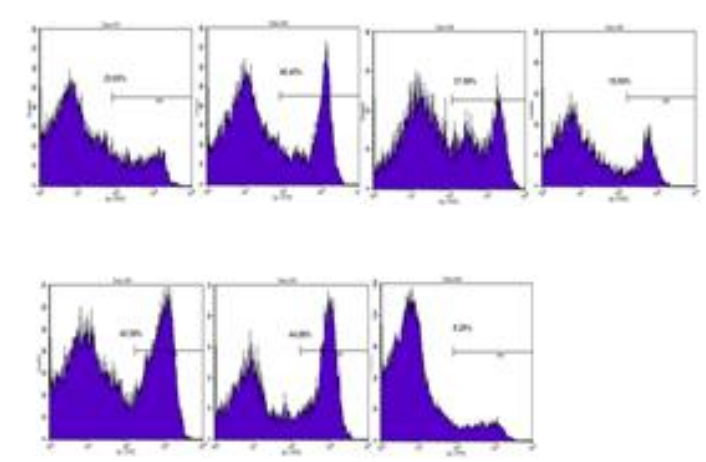

b

GR-1 $1^{+}$

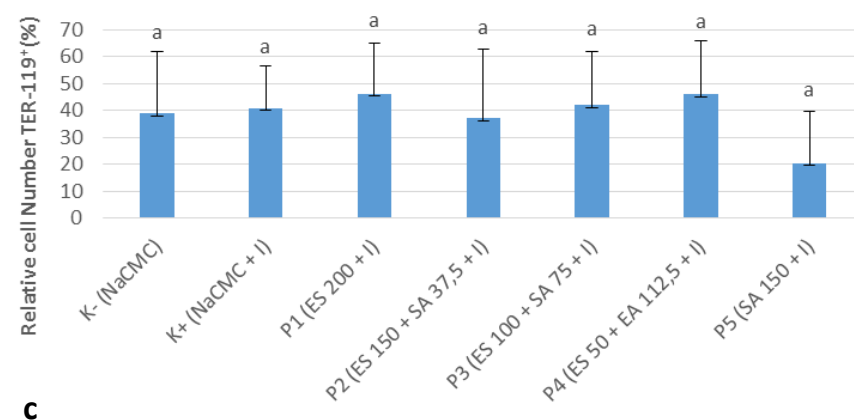

Dose Treatment

Figure 3. Expression of $\mathrm{GR} 1^{+}$cells

Description: $\mathrm{ES}=$ Elephantopus scaber, $\mathrm{SA}=$ Sauropus androgynus, I= infected by Salmonella typhimurium a. day surgery to $12^{\text {th }} ;$ b. day surgery to $18^{\text {th }} ;$ c. mean relative number of $\mathrm{GR} 1^{+}$cells $(\%)$

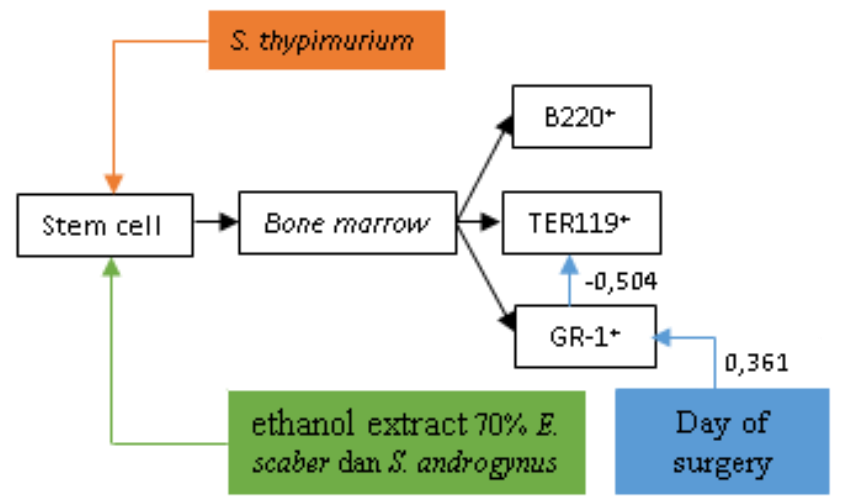

Figure 4. Development of $\mathrm{B} 220^{+}$cells, TER $119^{+}, \mathrm{GR}-1^{+}$on the organ affected Bone marrow by S. thypimurium infection and extract combinations of $E$. scaber and $S$. androgynus and day surgery

\section{CONCLUSION}

The combination of $E$. scaber and $S$. androgynus for $S$. thypimurium infected mice can restore the mice into their normal conditions. The best combination for $\mathrm{B}_{22} \mathrm{O}^{+}$cells is $\mathrm{P} 2$ treatment (150 mg. kg ${ }^{-1} \mathrm{BW}$ E. scaber and 37.5 $\mathrm{mg} . \mathrm{kg}^{-1} \mathrm{BW}$ S. androgynus. While the best dose for increasing TER $119^{+}$cells is P5 tretament ( $S$. androgynus $150 \mathrm{mg} \cdot \mathrm{kg}^{-1} \mathrm{BW}$, while the $\mathrm{GR}-1^{+}$cells affected by the surgery. These dose formulations can be used to optimize the number of lymphocytes and not harmful for the developing fetus.

\section{Acknowledgments}

Author would like to thank Prof. Muhaimin Rifa'i PhD, Yayu, Jannah and Lulut. We also thank our early laboratory colleage Yuyun, Bambang, Andi, Qonita and all those who have helped this research.

\section{REFERENCES}

[1] Mor, G. 2006. Immunology of pregnancy. Springer Science+Business Media, Inc. New York.

[2] Saito, S., A. Nakashima, T. Shima, M. Ito. 2010. Th1/Th2/Th17 and regulatory T-cell 
paradigm in pregnancy. Am. J. Reprod. Immunol. 73. 601-610.

[3] Prasetyono, D.S. 2008. Guidance preparation and pregnancy care. Diva Press, Yogyakarta.

[4] Muliawan, S.Y., L.H. Moehario, P. Sudarmono. 2000. Checking the validity of the test agglutinin $\mathrm{O}$ and $\mathrm{HS}$. typhi in enforcing the early diagnosis of Typhoid fever. Trisakti University. Jakarta.

[5] Chessed, G., I. James, A.B. Yako, K. Egbucha. 2013. Prevalence of Typhoid fever infection among pregnant women at the Antenatal Care Unit of Specialist Hospital, Yola North Local Government Area, Adamawa State, Nigeria. Int. Sci. Res. J. 4(2). 93-99.

[6] Sunarno. 2007. Phyllantus niruri L. effect in percentage of neutrophils, bacteria colonies spleen and liver histology mice Balb/C were infected by Salmonella thypimurium. Master Thesis. Diponegoro University. Semarang.

[7] Pradana, A.R.A., M.S. Djati, M. Rifa'I. 2013. Mobilization of CD4+, CD8+, and B220+ on broiler chicken spleen with feed contained Polyscias obtusa post infection of Salmonella typhimurium. J. Exp. Life Sci. 3(1). 7-12.

[8] Sudoyo, A.W., B. Setiyohadi, I. Alwi. 2006. Textbook of medicine $4 \mathrm{Ed}$. University of Indonesia Publishing Center, Faculty of Medicine. Jakarta. 749-754.

[9] Fadhilah, A., M.S. Djati. 2014. Pengaruh ekstrak daun Polyscia Obtusa dan Elephantopus Scaber L. terhadap sel B220+ dan TER $119+$ mencit Balb/C bunting yang diinfeksi bakteri Salmonella thypimurium. Jurnal Biotropika. 2(4). 218-222.

[10] Spelman, K., J.J. Burns, D. Nichols, N. Winters, S. Ottersberg, M. Tenborg. 2006. Modulation of cytokine expression by traditional medicines: a review of herbal immunomodulators. Altern. Med. Rev. 11. 128-146.

[11] Shingh, S.D.J. 2005. Wound healing activity of the leaf extracts and Deoxyelephantopi isolate from Elephantopus scaber Lin Phytochemistry. 37. 238-242.

[12] Paul, M., K.B. Anto. 2011. Antibacterial activity of Sauropus androgynus (L) Merr. Int. J. Plant Sci. 6(1). 189-192.

[13] Baratawidjaja, K.G. 2006. Basic immunology $7^{\text {th }}$ Ed. Faculty of Medicine, University of Indonesia. Jakarta.

[14] Saifulhaq, M. 2009. Pengaruh pemberian ekstrak buah mahkota dewa dosis bertingkat terhadap proliferasi limfosit Lien pada Mencit Balb/C. Biomedika. 1(2). 33-36.

[15] Lehner, M.D. 2001. Immunomodulation by endotoxin tolerance in murine models of inflammation and bacterial infection.PhD Thesis. University of Konstanz.

[16] Middleton, E., C. Kandaswami, T.C. Theoharides. 2000. The effects of plant flavonoids on mammalian cells: implication for inflammation, heart disease, and cancer. $J$. Pharmacol. 52(4). 673-751.

[17] Craxton, A., G. Shu, J.D. Graves, J. Saklatvala, E.G. Krebs, E.A. Clark. 1998. P38 MAPK is required for $C D 4$-induced gene expression and proliferation in B lymphocyte. J. Immunol. 161. 3225-323.

[18] Loeffler, A.V. Gabain, C. Klade. 2008. Development of novel vaccines: skills, knowledge and translational technologies. Springer Wein. New York.

[19] Martine, J.T. 2002. Heinz body anemia in cats. Vetenary Clinical Pathology Clerkship Program.http://www.vet.uga.edu. Accessed July $5^{\text {th }} 2014$.

[20] Ekman, P. 2001. Facial expressions. In: Blakemore, C., S. Jennett (Eds). Oxford Companion to the Body. Oxford University Press. London.

[21] Lestarini, I.A. 2008. Pengaruh pemberian Phyllanthus niruri $\mathrm{L}$ terhadap respon imunitas seluler Balb/C yang diinfeksi Salmonella thypimurium. PhD Thesis. Faculty of Medicine, Diponegoro University. Semarang.

[22] Cassatella. M.A., V. Huber, F. Calzetti, D. Margotto, N. Tamassia, G. Peri, A. Mantovani, L. Rivoltini, C Tecchio. 2006. Interferon-activated neutrophils store a TNF-related apoptosis-inducing ligand (TRAIL/Apo-2 ligand) intracellular pool that is readily mobilizable following exposure to proinflammatory mediators. J. Leukoc. Biol. 79(1).123-132. 